\title{
PROSTORSKE RAZLIKE V DOHODKIH PREBIVALSTVA MESTNE OBČINE LJUBLJANA
}

Projekt »Prostorske razlike v dohodkih prebivalstva Mestne občine Ljubljana« je naročila in v celoti financirala Mestna občina Ljubljana. Nosilec enoletne raziskave, ki je bila izvedena v letih 2001-2002, je bil Marko Krevs z Oddelka za geografijo Filozofske fakultete Univerze v Ljubljani.

Namen projekta je bil proučiti prostorske razlike $\mathrm{v}$ dohodkih prebivalcev Mestne občine Ljubljana in njihovo spreminjanje. Izhajali smo iz nesorazmerja med načeli prostorske enakosti in enakopravnosti ter $\mathrm{v}$ predhodnih raziskavah ugotovljenem povečanju dohodkovne neenakosti v Sloveniji. Za Mestno občino Ljubljana smo želeli ugotoviti, ali se naraščanje dohodkovne neenakosti v družbi odraža tudi v povečevanju dohodkovnih razlik med območji. Oceniti smo želeli, ali na podlagi merljivih značilnosti porazdelitve dohodkov prebivalstva po območjih zaznavamo določene vidike socialne kongregacije (kot prostovoljne oblike zgoščanja prebivalstva s sorodnimi značilnostmi) oziroma segregacije (kot neprostovoljne oblike zgoščanja prebivalstva s sorodnimi značilnostmi, ki je plod diskriminacije, tudi dohodkovne).

Dohodkovne razlike med območji analiziramo s pomočjo različnih metod (na primer z indeksom dohodkovne neenakosti, indeksom dohodkovne segregacije, Ginijevim koeficientom koncentracije, lokacijskim količnikom in drugimi). Proučitev prostorskega vidika spreminjanja dohodkov nam je omogočila podrobna proučitev kart ter proučitev spreminjanja dohodkov z oddaljevanjem od središča mesta Ljubljana. Razlago prostorskih razlik z vidika dohodkov prebivalstva pa nam je omogočila tudi analiza korelacijske povezanosti dohodkov z izbranimi značilnostmi prebivalstva (z izobrazbeno, starostno in nacionalno sestavo prebivalstva).

Ugotavljamo, da v Ljubljani obstajajo nekatera obmo-čja, na katerih je mogoče zaznati določene vidike socialne kongregacije, na primer velik del Rožne doline, Murgle, območje »Plave lagune«, nove t.i. nadstandardne soseske, kot so Zupančičeva jama, Bežigrajski dvor ali Stanovanjsko naselje Mostec, ter območji izrazitega povečevanja dohodkov, Ledina in Podutik. Težje v Mestni občini Ljubljana govorimo o območjih izrazite socialne segregacije, saj je težko dokazovati neprostovoljnost oziroma prisilnost priseljevanja prebivalstva na območja, kjer sicer ugotavljamo izredno nizke dohodke, obenem pa tudi izredno visok delež »neslovenskega« prebivalstva (na primer Rakova jelša).

Enostavnega odgovora na vprašanje, ali se na obravnavanem območju prostorske razlike z vidika dohodkov prebivalstva povečujejo, nismo dobili. Določeni vidiki dohodkovne neenakosti $\mathrm{v}$ MOL se povečujejo (na primer krepitev skupin prebivalcev z najnižjimi in najvišjimi dohodki na račun skupin s srednje visokimi dohodki; povečevanje prostorske koncentracije zavezancev v najnižjem dohodninskem razredu), drugi pa zmanjšujejo (na primer zmanjševanje prostorske koncentracije bruto osnove dohodnine in zavezancev v najvišjih dohodninskih razredih).

Marko Krevs 